International Journal of Current Advanced Research

ISSN: O: 2319-6475, ISSN: P: 2319 - 6505, Impact Factor: SJIF: 5.995

Available Online at www.journalijcar.org

Volume 6; Issue 4; April 2017; Page No. 3160-3161

DOI: http://dx.doi.org/10.24327/ijcar.2017.3161.0211

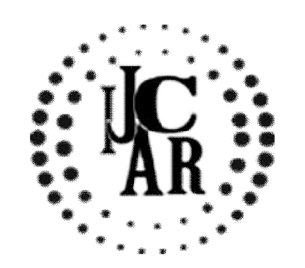

Research Article

\title{
PREFERENCE OF VERBAL VS VISUAL LEARNING AMONG DENTAL STUDENTS
}

\section{JayakeerthanaSrinivasan and Brundha M.P}

Saveetha Dental College and Hospital, Chennai

\begin{tabular}{l}
\hline A R T I C L E I N F O \\
\hline Article History: \\
Received $11^{\text {th }}$ January, 2017 \\
Received in revised form $19^{\text {th }}$ February, 2017 \\
Accepted $22^{\text {nd }}$ March, 2017 \\
Published online $28^{\text {th }}$ April, 2017 \\
\hline
\end{tabular}

Key words:

Visual Learning, Verbal Learning

\begin{abstract}
A B S T R A C T
Aim: Aim of the study is to know the preference of verbal vs visual learning among dental students.

Objective: To know whether verbal or visual learning is preferred among dental students. Background: A number of different models have been proposed to explain these varying learning styles. Among those styles visual and verbal is a style of learning. Visual learners remember best what they see: pictures, diagrams, flow charts, time lines, films, and demonstrations and they tend to be spatial, or relate to, and have an eye for, size and space. They must learn to take intensive notes, because they tend to forget spoken words and ideas. Verbal learners get more out of words: written and spoken explanations and often they retain the information given through repetition when they discuss or explain the material to others.

Reason: The purpose of our study here was to know whether the dental students prefer verbal or visual learning and to know which is more comfort to them.
\end{abstract}

Copyright $\mathrm{C} 2017$ JayakeerthanaSrinivasan and Brundha M.P. This is an open access article distributed under the Creative Commons Attribution License, which permits unrestricted use, distribution, and reproduction in any medium, provided the original work is properly cited.

\section{INTRODUCTION}

A number of different proposals have been proposed to explain these varying learning styles. Among those styles visual and verbal is a style of learning. Visual learners remember by what they see flowcharts, picture, images, films, and demonstrations and they tend to be spatialand have an eye for, size and space. (1)They must learn to take intensive notes, because they forget spoken words and ideas. Verbal learners get more out of words that is written and spoken explanations and often they retain the information given through repetition when they discuss or explain the material to others. (2) The purpose of our study here was to know whether the dental students prefer verbal or visual learning and to know which is more comfort to them. Group learning is used to teach students both by verbal and visual classes. Group work helps students learn to cooperate, count on member effort and achievement, and live with group outcomes. The idea is to give students a model of this important aspect of the working world. However, no matter how groups are structured, problems with group communication tend to persist, especially in asynchronous (e.g., Internet-based). All the group members do not contribute their share of work because of miscommunication, because some members may dominate the discussions to the detriment of the group process. Therefore, the availability of groupware to improve group communications in the classroom is welcomed by many educators.

*Corresponding author: JayakeerthanaSrinivasan

Saveetha Dental College and Hospital, Chennai
For example, Lotus Notes/Learning Space groupware is currently being utilized in over thirty higher education settings throughout the country.(8) In addition, even companies implement this new technology.As a result, groupware implementation in classrooms also provides students to experience real world, cutting edge technology. Paivio's Dual Coding Theory provides the concept of verbal versus visual learning preference [8], which addresses a person's preferred method of processing information. This theory proposes that information is either coded in a network composed of language based information (verbalsystem) or it is coded in a network composed of nonverbal information (visual system). This theory suggests that although everyone codes information in both subsystems to some extent, individuals differ in their preferred representational style. (3)Some people prefer verbal representations and others prefer visual representations. Prior experiences and innate ability both play a role in determining a person's preference [9]. Prior research has used the Individual Differences Questionnaire first validated by Harshman and Paivio [9] to measure students'learning style. For example, Butler and Mautz [7] found that students who preferred a visual learning setting benefited most from multimedia presentations.

\section{MATERIALS AND METHOD}

The study was conducted in Saveetha Dental College, Chennai with 100 students of second year in Bachelor of Dental Surgery (BDS). The students were asked to fill the standard questionnaire ' index of learning style questionnaire ' 
which contains 44 questions. The results were then tabulated and calculated.

\section{RESULTS AND DISCUSSION}

There are several types of learning style. visual and verbal style of learning are a type of learning style.visual learners learn through what they see and they understand better. Verbal learners learn through what they speak and hear. Student learning style is one of the aspects of student personality that appears to play a role in determining how much a student learns. Some fields, including engineering, are already implementing this idea in the classroom. For example, Felder [4] cites the use of learning style measures as one means of improving the match between instructors' methods and student learning. There are many dimensions of a student's learning style that may be important; this study examines the preference for learning verbally versus learning visually. Although there is no reason to think that students who have a preference for learning verbally will not be able to learn using technology, prior research has shown that student preferences may affect student learning, and a student may learn more if (s)he studies by a method that is consistent with these preferences [5]. If learning materials conflict with a student's preferred method of processing information, the materials may not be helpful to the student [6]. If the materials are consistent with the student's preference, use of the materials may benefit students [7].

Previous results shows visual style of learning is more preferred than verbal. $48 \%$ of students prefer visual style of learning, $12 \%$ of students prefer verbal style of learning and $40 \%$ of students are well balanced in both verbal and visual style of learning.So the students now mostly prefer visual education as it's very intuitive.

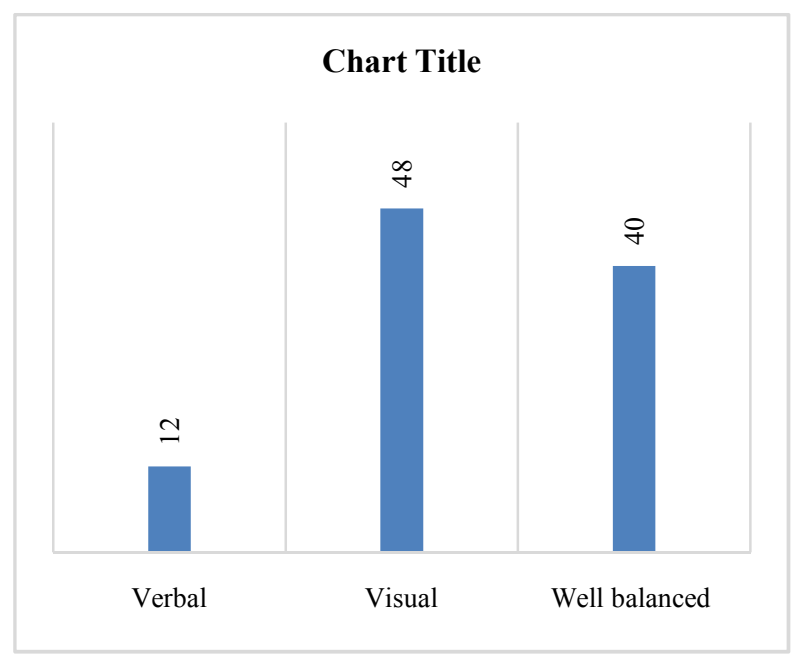

Graph 1 showing the comparison of verbal and visual learning

\section{CONCLUSION}

When asked most of the students said they remember best what they see-pictures, diagrams, flow charts, time lines, films, and demonstrations. Verbal learners get more out of words-written and spoken explanations which ain't that effective as they tend to get distracted easily. Everyone learns more when information is presented both visually and verbally. So visual learning is preferred more by students that verbal learning.

\section{Reference}

1. Wilson, E.V., Morrison, J.P. and A.M. Napier. 19971998. Perceived Effectiveness of Computer-Mediated Communications and Face-to-Face Communications in Student Software Development Teams. Journal of Computer Information Systems. Winter. pp.2-7.

2. Snow, R.E. 1989. Aptitude-Treatment Interaction as a Framework for Research on Individual Differences in Learning. In Ackerman, P.L., Sternberg, R.J. and Glaser, R., Eds., Learning and Individual Differences: Advances in Theory and Research. New York: W.H. Freeman and Company. pp.13-60.

3. Kozma. 1991. Learning with Media. Review of Educational Research. Summer, 179-211.

4. Felder, Richard. 1996. Matters of Style. ASEE Prism. Dec. 1, 1996. 6,4,pg. 18.

5. Cronbach, L. and Snow, R. 1989. Student Personality and the Environment for Learning. In Ackerman, P.L., Sternberg, R.J. and Glaser, R., Eds., Learning and Individual Differences: Advances in Theory and Research. New York: W.H. Freeman and Company. pp.

6. Pei and Reneau. 1990. The Effects of Memory Structure on Using Rule-Based Expert Systems for Training: A Framework and an Empirical Test. Decision Sciences. Spring, 263-286.

7. Butler and Mautz. 1996. Multimedia Presentations and Learning: A Laboratory Experiment. Issues in Accounting Education. 11,2,259-280.

8. Paivio. 1991. Dual Coding Theory: Retrospect and Current Status. Canadian Journal of Psychology. September, 255-287.

9. Harshman and Paivio. 1987. 'Paradoxical'Sex Differences in Self-Reported Imagery. Canadian Journal of Psychology. September, 287-302.

\section{How to cite this article:}

JayakeerthanaSrinivasan and Brundha M.P (2017) ' Preference Of Verbal Vs Visual Learning Among Dental Students', International Journal of Current Advanced Research, 06(04), pp. 3160-3161.

DOI: http://dx.doi.org/10.24327/ijcar.2017.3161.0211 